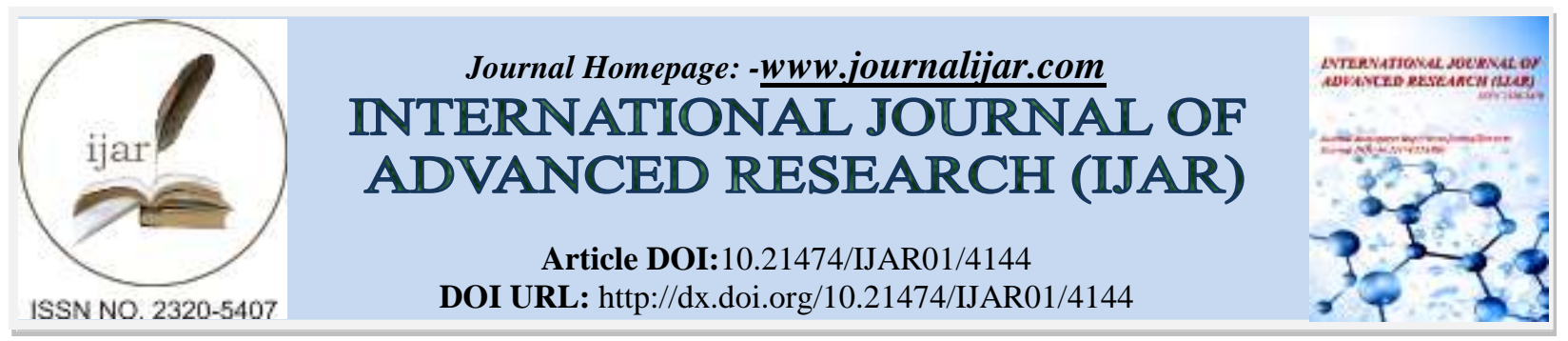

RESEARCH ARTICLE

\title{
INFLUENCE OF TEMPERATURE, GERMINATION DURATION AND CULTIVAR ON IN VITRO POLLEN GERMINATION AND POLLEN TUBE GROWTH IN COCONUT (COCOS NUCIFERA L.).
}

\author{
V.K.Chaturvedi ${ }^{1}$, K.B.Hebbar ${ }^{2}$, K.P.Chandran ${ }^{2}$, Regi Jacob Thomas ${ }^{1}$, M.Shareefa ${ }^{1}$, C.K.Nampoothiri ${ }^{1}$ and \\ Jinu Sivadasan ${ }^{1}$. \\ 1. I.C.A.R.-Central Plantation Crops Research Institute Regional Station, Kayamkulam-690533, Kerala, India. \\ 2. I.C.A.R.-Central Plantation Crops Research Institute, Kasaragod-671124, Kerala, India
}

\section{Manuscript Info}

\section{Manuscript History}

Received: 08 March 2017

Final Accepted: 04 April 2017

Published: May 2017

Key words:-

coconut, cultivars, pollen germination, tube length, temperature, duration.

\section{Abstract}

Temperature, germination duration and cultivars are important factors influencing pollen germination and pollen tube length of plants and thereby effecting fruit set and yield. To quantify the influence of nine temperatures from $10^{\circ} \mathrm{C}$ to $50^{\circ} \mathrm{C}$ at $5^{\circ} \mathrm{C}$ intervals, four germination durations of 1,3,5 and 7 hours and five coconut cultivars viz., WCT, CGD, MGD, MOD, MYD on in vitro pollen germination and pollen tube length, an investigation was carried out during 2014 and 2015 at C.P.C.R.I. Regional Station, Kayamkulam, India. Maximum pollen germination $(71 \%)$ and pollen tube length $(243 \mu \mathrm{m})$ was observed at $30^{\circ} \mathrm{C}$ and least at $50^{\circ} \mathrm{C}$. Pollen germination required 5 hours at $10-$ $20^{\circ} \mathrm{C}, 3$ hours at $25-35^{\circ} \mathrm{C}$ and 1 hour at $40-50^{\circ} \mathrm{C}$ for reaching maximum value. Pollen tube growth required 7 hours at $10^{\circ} \mathrm{C}, 5$ hours at 20 and $30^{\circ} \mathrm{C}, 3$ hours at $15,25,35$ and $40^{\circ} \mathrm{C}$ and 1 hour at 45 and $50^{\circ} \mathrm{C}$ to reach maximum value. WCT cultivar was found to have significantly more pollen germination percentage than the other cultivars. The cultivars which would perform better in predicted future climate change scenario are presented. Mean cardinal temperatures estimated for pollen germination and pollen tube length were $\mathrm{T}_{\text {opt. }}$ $28.5^{\circ} \mathrm{C}$ and $29.5^{\circ} \mathrm{C}, \mathrm{T}_{\text {min. }} 4.3^{\circ} \mathrm{C}$ and $8.5^{\circ} \mathrm{C}, \mathrm{T}_{\text {max. }} .52 .8^{\circ} \mathrm{C}$ and 51.2 ${ }^{\circ} \mathrm{C}$ respectively.

Copy Right, IJAR, 2016,. All rights reserved.

\section{Introduction:-}

Temperature is an important factor effecting growth, development and reproduction of plants. Fruit set in coconut is reduced, if temperature exceeds $33^{\circ} \mathrm{C}$ for prolonged periods during day, after inflorescence opening (Ranasinghe $e t$ $a l ., 2015)$. Fruit set and yield are dependent on pollen performance which is influenced by prevailing environmental temperature (Hedhly et al., 2005). Pollen grains are the only cells of plant that get detached from the plant into environment and get dispersed through bees and wind. Pollen grains finally succeed to reach and fertilize the ovule. Temperature at which in vitro pollen germination (IVPG) and pollen tube length (PTL) were maximum $\left(\mathrm{T}_{\mathrm{opt}}\right)$ has been reported for several fruit trees viz., Pears (Mellenthin et al., 1972), Papaya (Cohen et al., 1989), Pistacia (Acar and Kakani, 2010), cotton (Kakani et al., 2005). In coconut, the cardinal temperatures viz., the temperature at which pollen germination is maximum $\left(\mathrm{T}_{\mathrm{opt}}\right)$ has been reported to be $28^{\circ} \mathrm{C}$ and the temperature above which there is no pollen germination $\left(\mathrm{T}_{\max }\right.$ ) has been reported to be 39.7 for a coconut variety grown in Srilanka (Ranasinghe $e t$ al., 2015). In that study, the pollen response for the temperature range of $20^{\circ} \mathrm{C}$ to $38^{\circ} \mathrm{C}$ and for a germination 
duration of 24 hours was evaluated. In certain regions in India where coconut is grown, average minimum temperature reaches $15^{\circ} \mathrm{C}$ and average maximum temperature exceeds $35^{\circ} \mathrm{C}$. Determining the performance of pollen germination and pollen tube growth over a wide range of temperatures would give an indication of how the plant will perform at different temperatures in terms of growth and fruit set. Global warming and climate change trends indicate an increase of average minimum temperature by $1.86^{\circ} \mathrm{C}$ and maximum by $0.88^{\circ} \mathrm{C}$ over a 100 year period (Easterling et al., 1997). Determining the pollen germination and pollen tube growth in coconut cultivars keeping in view the future predicted trends in climate change, would be useful in identifying cultivars which would mitigate the adverse effects, if any, of climate change.

In groundnut, in vitro pollen germination was reported to be quite rapid and was completed in 45 minutes (Kakani et al., 2002). In Arabidopsis thaliana, a germination period of 16 hours was used to evaluate pollen germination in different varieties (Boavida and McCormick, 2007). No reports are available on the in vitro pollen germination and pollen tube growth at different duration of germinations for different cultivars of coconut. Hence the present study was conducted with the objectives of (1) quantifying the in vitro pollen germination and pollen tube growth in response to temperature, germination duration and cultivar (2) to determine the cultivars which are resilient and tolerant to different temperatures and (3) to estimate cardinal temperatures for pollen germination and pollen tube length of 5 coconut cultivars.

\section{Material and Methods:-}

Nine palms each of five cultivars commonly grown in Southern Kerala viz., West Coast Tall (WCT), Chowghat Green Dwarf (CGD), Malayan Green Dwarf (MGD), Malayan Orange Dwarf (MOD) and Malayan Yellow Dwarf (MYD) were selected from C.P.C.R.I. Regional Station Farm, Kayamkulam. The palms were in the age range 5-14 years; nut bearing and at least two palms of each cultivar were in flowering stage at the time of sampling. The palms were grown with recommended package of practices. Spikelets $(5 \mathrm{cms}$ to $13 \mathrm{cms}$ long) containing roughly equal amounts of slightly opened, partially opened and fully opened flowers were cut from the palms on the sampling day between 11 A.M. to 4 P.M. during the months from June to December in 2014 and from June to September in 2015. The spikelets were brought to laboratory within 1 hours of cutting. About 50 flowers total, containing the three types of opened flowers were detached with forceps or knife or hand from the spikelets and placed over butter paper kept in a petridish (10 cm dia.) lid. The lids with flowers of each cultivar were kept on an aluminum tray which was placed $250 \mathrm{cms}$ below a 100 watt lit tungsten bulb overnight to drive away minute insects and dry the anthers. Next day, the pollen from anthers was shed by brushing with nylon brush, tapped with forceps and by dropping the flower from a height into the petri dish. The collected pollen was mixed with nylon brush, minute insects were removed and with the use of the brush, the pollen was uniformly dusted on germination media which was solidified on the surface of slide $(7.5 \times 2.5 \mathrm{~cm})$. Less than $1 \mathrm{mg}$ of pollen was required for each slide.

The germination media consisted of $10 \%$ sucrose, $0.01 \% \mathrm{H}_{3} \mathrm{BO}_{3}, 0.025 \% \mathrm{Ca}\left(\mathrm{NO}_{3}\right)_{2}, 0.02 \% \mathrm{MgSO}_{4}$ and $0.01 \%$ $\mathrm{KNO}_{3}$ (Niles and Quesenberry, 1992). The media was solidified with $2 \%$ agar. Hot liquid media containing $2 \%$ agar were poured onto $7.5 \times 2.5 \mathrm{~cm}$ slides to cover it completely without allowing it to overflow and allowed to solidify. Using nylon brush, pollen was dusted carefully across the solidified media on each slide by gently tapping the nylon brush. One slide was prepared for each cultivar and kept in separate petridishes over crude filter paper wetted with distilled water and any excess water was drained out. The petridishes were covered with lid and placed in B.O.D. incubator/incubator at the set temperatures between 10 to $50^{\circ} \mathrm{C}$ at $5^{\circ} \mathrm{C}$ intervals. The incubator was set at the required temperature and verified by placing a standard glass thermometer near the petridish throughout the determination. No difference was observed between the set temperature and that in the thermometer kept besides the petridishes. Media temperature was not determined.

In vitro pollen germination (PG) and pollen tube length (PTL) were determined at 1,3,5 and 7 hours intervals after placing the petridishes with slides and pollen in incubator. They were determined using Carl Zeiss Axioskop 40 microscope with a W-Pi 10x/23 eyepiece and A-Plan 10x/0.25 objective. PTL was determined using Catcam 300 camera with compatible image processor software in the computer. PG was determined in 1-3 fields at random on each slide in a total of at least 150 pollen grains in first year. Pollen was counted as germinated if its tube length was equal to or exceeded the grain diameter. PG was determined in the second year in 5-50 image capture fields in total of at least 150 pollen grains and PTL was measured for at least 20 pollen at random obtained in these fields (Kakani et al., 2002). PG percentage was calculated by dividing the number of pollen germinated by the total number of pollen counted and then multiplied with 100. Mean PTL of 20 pollen grains was calculated. The experiment was conducted twice in each of two consecutive years. Each experiment was a replicate which was completed within 3 
successive months. In the second year, PTL was also recorded. On any given day, PG and PTL of all five cultivars were determined at a randomly selected temperature out of the 9 temperatures studied in each experiment.

The pooled data of four replicates for PG and two for PTL were statistically analyzed by the analysis of variance as for a three factor (Rangaswamy, 2000). Fisher's Least Significant Difference (LSD) at $\mathrm{P} \leq 0.05$ were used to compare mean values of factors. Cubic, quadratic and modified bilinear regression models were tested for their best fit to the data of maximum PG percentage and PTL recorded at the 7 hour germination period. The regression coefficient values, $\mathrm{R}^{2}$, and RMSD for the data were determined for the three regression models by standard procedures (Kakani et al., 2002; Rangaswamy, 2000). using the mean values of the 7 hour germination duration only for comparison. The modified bilinear equation was found to give the best fit for the data. Hence cardinal temperatures derived by modified bilinear equation only are reported. The cardinal temperatures were determined using the mean value of all replications of PG and PTL for the 1,3,5 and 7 hour germination durations at different temperatures.. The modified bilinear regression coefficients were determined as per the equation (Kakani et al., 2002) which is given below:

Pollen germination $(\%)$ or pollen tube length $=$

$$
\mathrm{a}+\left[\mathrm{b}_{1}\left(\mathrm{~T}-\mathrm{T}_{\text {opt }}\right)\right]+\mathrm{b}_{2}\left[\mathrm{ABS}\left(\mathrm{T}_{\text {opt }} \mathrm{T}\right)\right]
$$

Where $T$ is temperature and $T_{o p t}, a, b_{1}$ and $b_{2}$ are genotype specific constants. $T_{\text {opt }}$ were determined using modified Newton-Gauss iterative method based on lowest RMSD values between observed and predicted values for each cultivar (Kakani et al., 2005). After determining the $\mathrm{T}_{\text {opt }}$, the remaining two cardinal temperatures viz., $\mathrm{T}_{\min }$ (temperature below which no pollen germination would occur) and $\mathrm{T}_{\max }$ (temperature above which no pollen germination would occur) were determined from the modified bilinear equation constants using the following equations:

$$
\begin{array}{ll}
\mathrm{T}_{\min }= & {\left[\mathrm{a}+\left(\mathrm{b}_{2}-\mathrm{b}_{1}\right) \times \mathrm{T}_{\mathrm{opt}}\right]} \\
\mathrm{b}_{2}-\mathrm{b}_{1} & \\
\mathrm{~T}_{\max }= & {\left[\left(\mathrm{b}_{1}+\mathrm{b}_{2}\right) \times \mathrm{T}_{\mathrm{opt}}-\mathrm{a}\right]} \\
\overline{\mathrm{b}}_{1}+\mathrm{b}_{2}
\end{array}
$$

The values of $T_{\min }$ or $T_{\max }$ which were determined for each cultivar using equations (2) and (3) were verified for their correctness by using them as $\mathrm{T}$ in the equation (1) and finding out whether they gave the required pollen germination or pollen tube length value of 0 in all cases. The regression equations derived from the data are presented in table 1 which could be used to determine the pollen performance of the 5 coconut cultivars at any of the future predicted climate change temperature scenarios.

Table 1:- Modified bilinear regression equations for the 5 coconut cultivars for pollen germination and pollen tube length.

\begin{tabular}{|c|c|c|c|}
\hline Cultivar & Modified bilinear regression equation for pollen germination & $\mathrm{R}^{2}$ & RMSD \\
\hline WCT & $74.30-[0.53(\mathrm{~T}-29.1)]-2.92[\mathrm{ABS}(29.1-\mathrm{T})]$ & 0.88 & 7.0 \\
\hline CGD & $43.05+[0.02(\mathrm{~T}-29.1)]-1.60[\mathrm{ABS}(29.1-\mathrm{T})]$ & 0.84 & 4.37 \\
\hline MGD & $59.89+[0.81(\mathrm{~T}-25.4)]-2.89[\mathrm{ABS}(25.4-\mathrm{T})]$ & 0.80 & 8.62 \\
\hline MYD & $52.12+[0.04(\mathrm{~T}-29.0)]-2.30[\mathrm{ABS}(29.0-\mathrm{T})]$ & 0.86 & 6.02 \\
\hline MOD & $58.74-[0.25(\mathrm{~T}-30)]-2.60[\mathrm{ABS}(30-\mathrm{T})]$ & 0.88 & 6.31 \\
\hline & Modified bilinear regression equation for pollen tube length & & \\
\hline WCT & $183.1+[0.34(\mathrm{~T}-27)]-8.57[\mathrm{ABS}(27-\mathrm{T})]$ & 0.83 & 25.34 \\
\hline CGD & $178.70+[1.02(\mathrm{~T}-28.5)]-8.38[\mathrm{ABS}(28.5-\mathrm{T})]$ & 0.86 & 21.35 \\
\hline MGD & $185.88-[0.41(\mathrm{~T}-31.1)]-9.08[\mathrm{ABS}(31.1-\mathrm{T})]$ & 0.81 & 27.2 \\
\hline MYD & $184.19-[0.29(\mathrm{~T}-30.5)]-8.67[\mathrm{ABS}(30.5-\mathrm{T})]$ & 0.82 & 23.79 \\
\hline MOD & $182.27+[0.06(\mathrm{~T}-30.2)]-8.27[\mathrm{ABS}(30.2-\mathrm{T})]$ & 0.74 & 30.13 \\
\hline
\end{tabular}




\section{Results and Discussion:-}

Temperature:-

Temperature significantly influenced PG (Fig. 1) and PTL (Fig. 2). Maximum PG and PTL were observed at $30^{\circ} \mathrm{C}$ and least at $50^{\circ} \mathrm{C}$ on an average over germination durations and cultivars. At temperatures above or below this optimum temperature $\left(30^{\circ} \mathrm{C}\right)$, PG and PTL showed a linear decrease with further change in temperature. Maximum $\mathrm{PG}$ of $41 \%$ at $27^{\circ} \mathrm{C}$ in MGD cultivar in Mexico and $38 \%$ at the $\mathrm{T}_{\text {opt }}$ of $28^{\circ} \mathrm{C}$ in a commercial variety in Sri Lanka, has been reported by earlier workers (Armendariz et al., 2006; Ranasinghe et al., 2010). In the present study, a mean maximum pollen germination of $71 \%$ for the 5 cultivars was obtained at the observed $\mathrm{T}_{\text {opt }}$ of $30^{\circ} \mathrm{C}$ and the 7 hour germination duration which is much higher than that reported by others in coconut (Armendariz et al., 2006; Ranasinghe et al., 2010). This difference might be mainly due to the differences in the concentrations of nutrients and agar in the germination media used in these studies and the maturity of the flowers at sampling.

Fig: 1:- Percentage of pollen germinated at different temperatures in coconut (average over germination durations and cultivars).

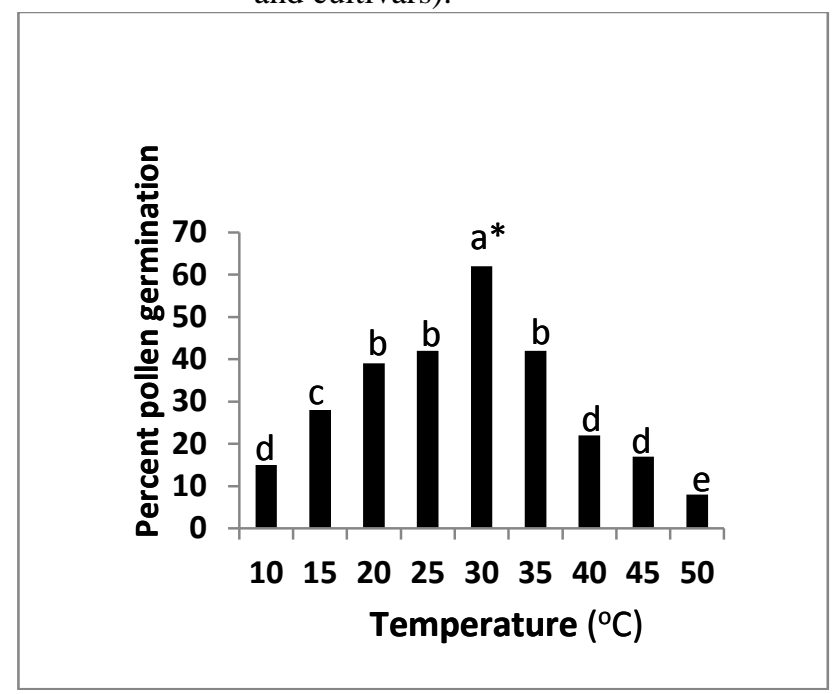

*Bars with any common alphabet above them are not significantly different at $\mathrm{P}<0.05$

Fig 2:- Pollen tube length at different temperatures in coconut (average over germination durations and cultivars).

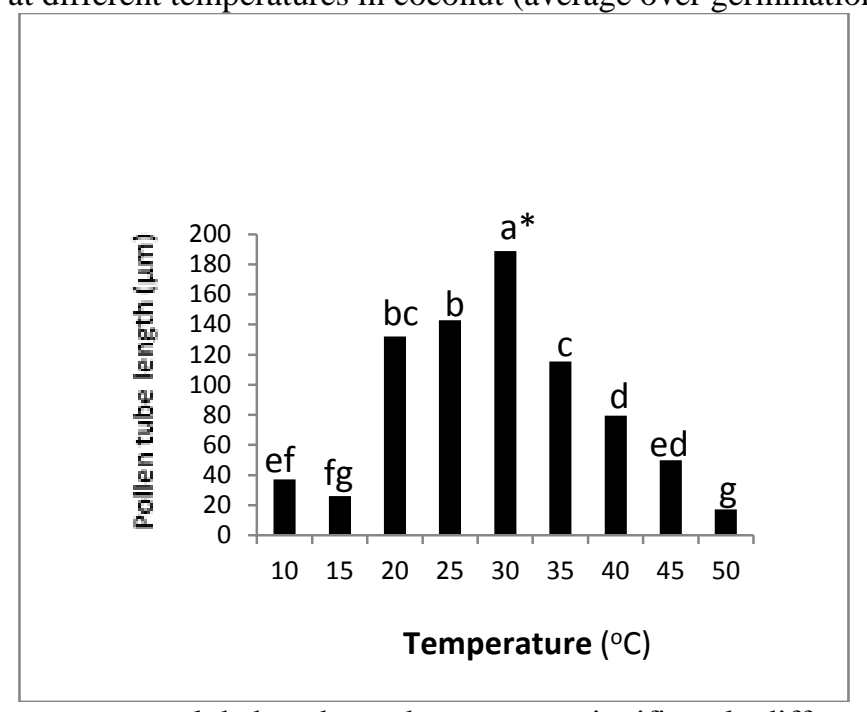

*Bars with any common alphabet above them are not significantly different at $\mathrm{P}<0.05$ 


\section{Germination Duration:-}

PG and PTL needed 5 and 7 hours of incubation with germination media respectively, to reach a constant maximum value, on an average over temperatures and cultivars (Fig.3 and 4). However, germination duration x temperature interaction was also found to be significant. This indicated that germination duration required for maximum pollen germination and pollen tube length varied with temperature. Pollen germination required 5 hours at $10-20^{\circ} \mathrm{C}, 3$ hours at $25-35^{\circ} \mathrm{C}$ and 1 hour at $40-50^{\circ} \mathrm{C}$ for reaching maximum value. Pollen tube growth required 7 hours at $10^{\circ} \mathrm{C}, 5$ hours at 20 and $30^{\circ} \mathrm{C}, 3$ hours at $15,25,35$ and $40^{\circ} \mathrm{C}$ and 1 hour at 45 and $50^{\circ} \mathrm{C}$ to reach maximum value (Table 2). In coconut, it has been reported that pollen germination required 16 hours to reach maximum value after incubating with growth media (Ranasinghe et al., 2010). . In the present study a 5 hour germination period was found adequate for completion of pollen germination, irrespective of the cultivar or temperature. This faster pollen germination in the present study might possibly due to differences in the concentration of nutrients used in the germinating media in the present study as compared to that used by earlier workers. The media used in the present study was same as that used in groundnut (Kakani et al., 2002) wherein pollen germination and pollen tube growth were reported to be faster and were completed within 45 to 240 minutes.

\section{Cultivars:-}

WCT cultivar had maximum pollen germination which was significantly higher than that of the four dwarf cultivars, on an average over germination durations and temperatures (Fig 5). The four dwarf cultivars were on par in pollen germination. Pollen tube lengths of all five cultivars were similar (Table 4). Significant differences in pollen germination and pollen tube

length due to genotypes have been reported in cotton (Kakani et al., 2005)and Pistacia (Acar and Kakani 2010). In the present study variability in pollen tube length among the coconut cultivars was not much. Cultivar $\mathrm{x}$ temperature interaction was significant for pollen germination indicating that cultivar differences in pollen germination varied with temperature. Cultivar exhibiting pollen germination on par with the highest at specific temperatures were WCT,MGD, MOD at 30 and $35^{\circ} \mathrm{C}$; WCT at $25^{\circ} \mathrm{C}$; MGD, WCT at $20^{\circ} \mathrm{C}$; WCT,CGD, MOD at $15^{\circ} \mathrm{C}$ and WCT, CGD at $10^{\circ} \mathrm{C}$. At temperatures from 40 to $50^{\circ} \mathrm{C}$ all cultivars had similar pollen germination percentage (Table 3). In the present study WCT, MGD and MOD are identified as suitable cultivars for regions where the increase in maximum temperature due to future predicted climate change, would lie between 30 to $40^{\circ} \mathrm{C}$. WCT, CGD and MOD are identified as suitable cultivars for regions where the increase in mean minimum temperature, due to climate change, would lie between 10 to $20^{\circ} \mathrm{C}$. WCT and MGD are cultivars which would be most benefitted when the increase in mean monthly temperatures, lies between 20 to $30^{\circ} \mathrm{C}$ due to climate change.

Fig: 3:- Percentage of pollen germinated after different germination durations (average over cultivars and temperatures).

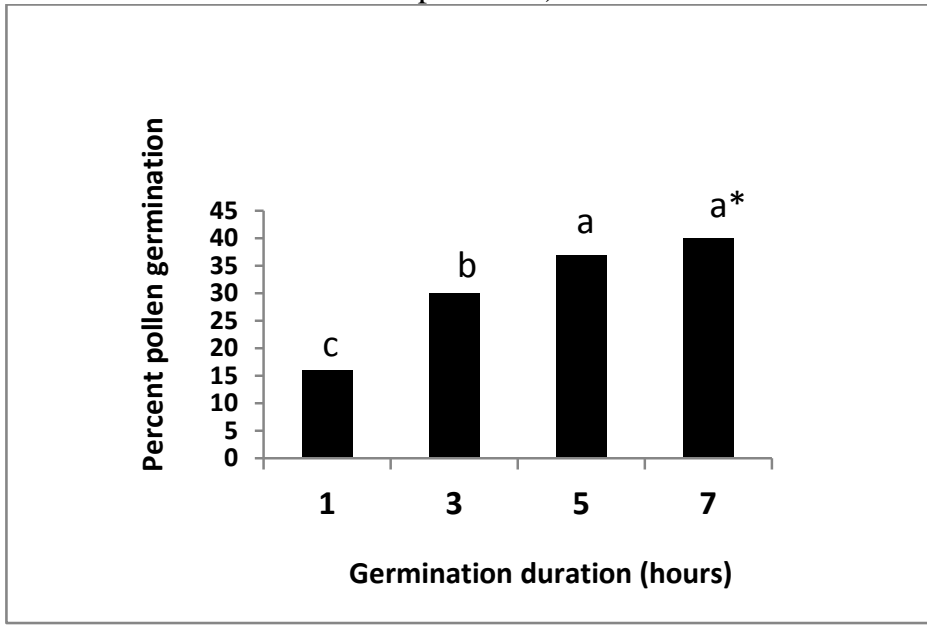

*Bars with any common alphabet above them are not significantly different at $\mathrm{P}<0.05$

In a study with 12 cotton cultivars (Kakani et al., 2005) it was concluded that cultivars having higher maximum pollen germination, higher maximum pollen tube length and an optimum temperature $>32^{\circ} \mathrm{C}$ for maximum pollen germination in vitro can be used for screening cultivars to high temperature tolerance. In thepresent study WCT, 
MOD and MGD had the higher pollen germination percentage at the meanoptimum temperature of $30^{\circ} \mathrm{C}$ and were also found to have higher pollen germination percentage at higher temperatures between 30 to $40^{\circ} \mathrm{C}$ (Table 4 ) indicating their heat tolerance.

Fig: 4. Pollen tube length after different germination durations (average over cultivars and temperatures).

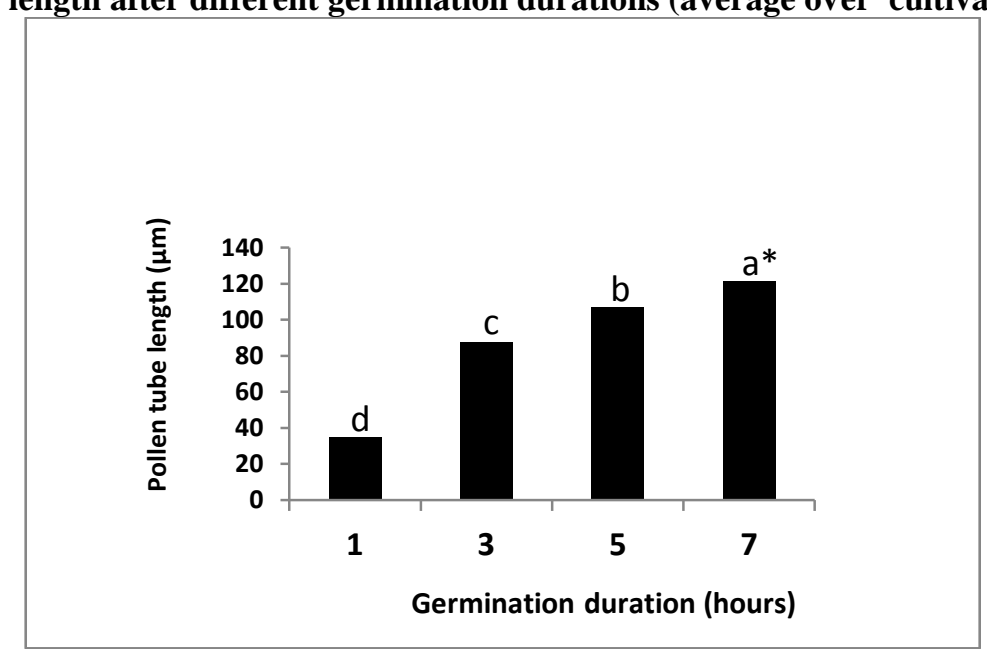

*Bars with any common alphabet above them are not significantly different at $\mathrm{P}<0.05$

\section{Cardinal temperatures:-}

In certain other crops viz., Pistacia (Acar and Kakani, 2010) and cotton (Kakani et al., 2005) cultivars differences in $\mathrm{T}_{\mathrm{opt}}$ for both PG and PTL have been reported. In the present study, although significant differences in $\mathrm{T}_{\mathrm{opt}}$ forPTL and $\mathrm{T}_{\max }$ for pollen germination were found among cultivars (Table 4), but the actual data indicated no difference among cultivars for pollen tube length (Table 4) and pollen germinationat $50^{\circ} \mathrm{C}$ (Table 3 ). Probably the coconut cultivars used in the present study evolved and became well adapted to the climatic conditions of Kerala where these are grown and had similar $\mathrm{T}_{\mathrm{opt}}$ for PG and PTL. In Kerala the mean monthly temperatures throughout the year are found to vary between 27 to $29^{\circ} \mathrm{C}$, which is close to the optimum found in the present study.

Table 2:-Germination duration for maximum pollen germination and pollen tube length at different temperatures (average over cultivars).

\begin{tabular}{|c|c|c|}
\hline \multirow{2}{*}{ Temperature ${ }^{\circ} \mathrm{C}$} & \multicolumn{2}{|c|}{ Duration (hours) required for maximum } \\
\cline { 2 - 3 } & Pollen germination & Pollen tube length \\
\hline 10 & 5 & 3 \\
\hline 15 & 5 & 5 \\
\hline 20 & 5 & 3 \\
\hline 25 & 3 & 5 \\
\hline 30 & 3 & 3 \\
\hline 35 & 3 & 3 \\
\hline 40 & 1 & 1 \\
\hline 45 & 1 & 1 \\
\hline 50 & 1 & \\
\hline
\end{tabular}


Fig: 5:-Percent pollen germinated in different cultivars of coconut (average over germination durations and temperatures).

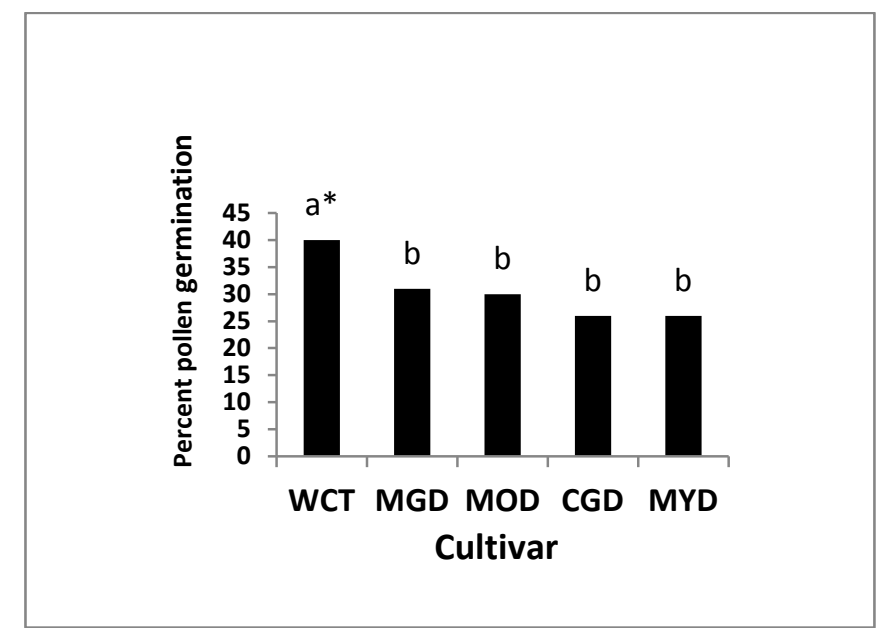

*Bars with any common alphabet above them are not significantly different at $\mathrm{P}<0.05$

Table 3:- Cultivars having pollen germination on par with highestobserved at the given temperature (averaged over germination durations).

\begin{tabular}{|c|c|c|}
\hline Temperature ${ }^{\circ} \mathrm{C}$ & Cultivars & $\begin{array}{l}\text { Ranges of mean pollen } \\
\text { germination } \begin{array}{c}\text { mercentage of } \\
\text { the } \\
\text { mentioned cultivars }\end{array}\end{array}$ \\
\hline 10 & WCT,CGD & $27-42$ \\
\hline 15 & WCT,CGD,MGD, & $50-56$ \\
\hline 20 & WCT,MGD & 61 \\
\hline 25 & WCT & $61-76$ \\
\hline 30 & WCT,MOD,MGD & $44-56$ \\
\hline 35 & WCT,MGD,MOD & $19-24$ \\
\hline 40 & CGD,MGD,WCT,MYD,MOD & $16-20$ \\
\hline 45 & WCT,CGD,MGD,MOD,MYD & $6-12$ \\
\hline 50 & CGD,MGD,MYD,MOD,WCT & \\
\hline
\end{tabular}

\section{Conclusion:-}

A temperature of $30^{\circ} \mathrm{C}$ was found optimum for obtaining maximum PG and PTL in the coconut cultivars. PG and PTL required longer durations $\left(3-7\right.$ hours) for completion at lower temperatures $\left(<40^{\circ} \mathrm{C}\right)$ than at higher temperatures $\left(>40^{\circ} \mathrm{C}\right)$ (1-3hours). WCT cultivar had significantly higher pollen germination than the other 4 cultivars. WCT, MGD and MOD cultivars would perform better in predicted future climate change, in regions where mean maximum temperature falls in the range $30^{\circ} \mathrm{C}$ to $40^{\circ} \mathrm{C}$. WCT, CGD and MOD would perform better in predicted future climate change, in regions where mean minimum temperature falls in the range 10 to $20^{\circ} \mathrm{C}$.Mean cardinal temperatures for the coconut cultivars for PG and PTL were $\mathrm{T}_{\text {opt }} 28.5^{\circ} \mathrm{C}$ and $29.5^{\circ} \mathrm{C}, \mathrm{T}_{\text {min }} 4.3^{\circ} \mathrm{C}$ and $8.5^{\circ} \mathrm{C}$ $\mathrm{T}_{\max } 52.8^{\circ} \mathrm{C}$ and $51.2^{\circ} \mathrm{C}$ repectively. As pollen germination and pollen tube length did not cease completely at the Table 4:- Mean values of maximum pollen germination percentage, pollen tube length and the cardinal temperatures obtained for the five cultivars.

\begin{tabular}{|c|c|c|c|c|c|c|c|c|}
\hline \multirow[t]{2}{*}{ Cultivar } & \multirow{2}{*}{$\begin{array}{l}\text { Maximum } \\
\text { Pollen } \\
\text { germination } \\
\text { percentage }\end{array}$} & \multirow{2}{*}{$\begin{array}{l}\text { Maximum } \\
\text { Pollen tube } \\
\text { length }(\mu \mathrm{m})\end{array}$} & \multicolumn{2}{|c|}{$\mathrm{T}_{\mathrm{opt}}{ }^{\circ} \mathrm{C}$} & \multicolumn{2}{|c|}{$\mathrm{T}_{\min }{ }^{\circ} \mathrm{C}$} & \multicolumn{2}{|c|}{$\mathrm{T}_{\max }{ }^{\circ} \mathrm{C}$} \\
\hline & & & PG & PTL & PG & PTL & PG & PTL \\
\hline WCT & 83 & 248 & 29.1 & 27.0 & -2.0 & 6.5 & 50.6 & 49.2 \\
\hline CGD & 52 & 216 & 29.1 & 28.5 & 2.6 & 9.5 & 56.4 & 52.8 \\
\hline MGD & 73 & 267 & 25.4 & 31.1 & 9.2 & 9.7 & 54.2 & 50.7 \\
\hline MYD & 71 & 241 & 29.0 & 30.5 & 6.7 & 8.5 & 52.1 & 51.1 \\
\hline MOD & 76 & 244 & 30.0 & 30.2 & 5.0 & 8.3 & 50.6 & 52.4 \\
\hline
\end{tabular}




\begin{tabular}{|c|c|c|cc|cc|c|c|}
\hline Mean & 71 & 243 & 28.5 & 29.5 & 4.3 & 8.5 & 52.8 & 51.2 \\
\hline LSD $(\mathrm{P} \leq 0.05)$ & 10 & ${ }^{\alpha} \mathrm{NS}$ & $\mathrm{NS}$ & 2.9 & $\mathrm{NS}$ & $\mathrm{NS}$ & 3.8 & $\mathrm{NS}$ \\
\hline
\end{tabular}

${ }^{\alpha}$ Not significant

$10^{\circ} \mathrm{C}$ and $50^{\circ} \mathrm{C}$, further studies using temperature from $-5^{\circ} \mathrm{C}$ to $60^{\circ} \mathrm{C}$ would be required to obtain accurate values of $\mathrm{T}_{\min }$ and $\mathrm{T}_{\max }$ for pollen germination and pollen tube length.

\section{Acknowledgement:-}

The authors are thankful to the Head, C.P.C.R.I. Regional Station, Kayamakulam and the Director, C.P.C.R.I., Kasargod, for providing necessary facilities for carrying out this study.

\section{References:-}

1. Acar I, Kakani VG. (2010). The effects of temperature on in vitro pollen germination and pollen tube growth of Pistacia spp. Scientia Horticulturae125:569-572.

2. Armendariz BHC, Oropeza C, Chan JL, Maust B, Torres N, Aguilar CDLCC,Saenz L. (2006). Pollen fertility and female flower anatomy of micropropagated coconut palms. Revista Fitotecnia Mexicana 29:373-378.

3. Boavida LC, McCormick S. (2007). Temperature as a determinant factor for increased and reproducible in vitro pollen germination in Arabidopsis thaliana. The Plant Journal 52:570-582.

4. Cohen E, Lavi U, Spiegel R. (1989). Papaya pollen viability and storage. Scientia Horticulturae 40:317-324.

5. Easterling DR, Horton B, Jones PD et al. (1997) Maximum and minimum temperature trends for the globe. Science 277:364-367.

6. Hedhly A, Hormaza JI, Herrero M. (2005). The effect of temperature on pollen germination, pollen tube growth and stigmatic receptivity in peach. Plant Biol. J. 7:476-483.

7. Kakani VG, Prasad PVV, Craufurd PQ, Wheeler TR. 2002. Response of in vitro pollen germination and pollen tube growth of groundnut (Arachis hypogea L.) genotypes to temperature. Plant, Cell \& Environment 25:16511661.

8. Kakani VG, Reddy KR, Koti S, Wallace TP, Prasad PVV, Reddy VR, Zhao D. (2005).Differences in in vitro pollen germination and pollen tube growth of cotton cultivars in response to high temperature. Annals of Botany 96:59-67.

9. Mellenthin WM, Wang CY, Wang SY. (1972) Influence of temperature on pollen tubegrowth and initial fruit development in 'D'Anjou' pear. Hort. Sci. 7:557-559.

10. Niles WL, Quesenberry KH. (1992). Pollen germination of rhizoma peanut cv. Florigraze. Peanut Science 19:105-107.

11. Ranasinghe CS, Silva LRS, Premasiri RDN. (2015). Major determinants of fruit set and yield fluctuation in coconut (Cocos nucifera L). J Nat. Sci. Foundation of Sri Lanka43:253-264.

12. Ranasinghe CS, Waidyarathna KP, Pradeep IAPC, Meneripitiya MSK. (2010). Approach to screen coconut varieties for high temperature tolerance by in-vitro pollen germination. Cocos 19:1-12.

13. Rangaswamy, R. (2000). A textbook of Agricultural Statistics, New Age International (P) Limited, New Delhi, India, pp.203-210 and 333-358. 